\title{
Wind Turbine Power Performance Testing using Nacelle Transfer Function
}

\author{
나셀 변환 함수를 이용한 풍력터빈 출력성능평가 \\ Kim, Hyeon-Wu', Ko, Kyung-Nam ${ }^{* * \dagger}$ and Huh, Jong-Chul ${ }^{* * *}$ \\ 김현우 ${ }^{*}$ 고경남** · 허종철 ${ }^{\star \star *}$
}

(Submit date : 2013. 5. 11., Judgment date : 2013. 5. 13., Publication decide date : 2013. 8. 20.)

\begin{abstract}
A study on power performance testing of a wind turbine which has no met-mast at a distance of 2 4 rotor diameter was carried out using the Nacelle Transfer Function, NTF, according to IEC 61400-12-2. The wind data for this study was measured at HanKyoung wind farm of Jeju Island. The NTF was modeled using the correlation between wind speeds from the met-mast and from the wind turbine nacelle within $2 \sim 4$ rotor diameter from the met-mast. The NTF was verified by the comparison of estimated Annual Energy Productions, AEPs, and binned power curves. The Nacelle Power Curve, NPC, was derived from the nacelle wind speed data corrected by NTF. The NPC of wind turbine under test and the power curve offered by the turbine manufacturer were compared to check whether the wind turbine is properly generating electricity. Overall the NPC was in good agreement with the manufacturer's power curve. The result showed power performance testing for a wind turbine which has no met-mast at a distance of $2 \sim 4$ rotor diameter was successfully carried out in compliance with IEC 61400-12-2.
\end{abstract}

Key Words : Wind energy(풍력에너지), Power performance testing(출력성능평가), Nacelle transfer function(나셀 변환함수), Nacelle power curve(나셀 출력곡선)

Nomenclature

AEP : Annual energy production

NTF : Nacelle transfer function
NPC : Nacelle power curve

WTG : Wind turbine generator

WS : Wind speed $(\mathrm{m} / \mathrm{s})$

WD : Wind direction $\left(^{\circ}\right)$
**† 고경남(교신저자) :

제주대학교 대학원 풍력특성화협동과정, 조교수

E-mail : gnkor2@jejunu.ac.kr, Tel : 064)754-4401

*김현우 : 제주대학교 대학원 풍력특성화협동과정, 석사과정

***허종철 : 제주대학교 기계공학과, 교수

\section{$* * \dagger$ Ko, Kyung-Nam(corresponding author) :} Interdisciplinary Postgraduate Program in Wind Energy, Jeju National University.

E-mail : gnkor2@jejunu.ac.kr, Tel : 064)754-4401

*Kim, Hyeon-Wu : Interdisciplinary Postgraduate Program in Wind Energy, Jeju National University.

***Huh, Jong-Chul : Department of Mechanical Engineering, Jeju National University. 


\begin{tabular}{|c|c|}
\hline GL & Above ground level (m) \\
\hline RIX & Ruggedness index \\
\hline $\mathrm{PC}$ & Power curve \\
\hline $\mathrm{L}$ & $\begin{array}{l}\text { Distance from wind turbine to } \\
\text { met-mast }(\mathrm{m})\end{array}$ \\
\hline$C_{p}$ & Power coefficient \\
\hline $\mathrm{V}_{\text {nacelle, } \mathrm{i}}$ & $\begin{array}{l}\text { Average of the nacelle wind speed } \\
\text { in bin } \mathrm{i}(\mathrm{m} / \mathrm{s})\end{array}$ \\
\hline$V_{\text {free, }}$ & $\begin{array}{l}\text { Average of the met-mast wind } \\
\text { speed in bin } i(\mathrm{~m} / \mathrm{s})\end{array}$ \\
\hline$V_{\text {free }}$ & $\begin{array}{l}\text { Free wind speed estimated using } \\
\text { measured nacelle and met-mast } \\
\text { wind speed data }(\mathrm{m} / \mathrm{s})\end{array}$ \\
\hline$V_{n}$ & Normalized wind speed $(\mathrm{m} / \mathrm{s})$ \\
\hline$\rho_{1}$ & Measured air density $\left(\mathrm{kg} / \mathrm{m}^{3}\right)$ \\
\hline $\mathrm{P}_{0}$ & $\begin{array}{l}\text { The reference air density of } \\
1.225 \mathrm{~kg} / \mathrm{m}^{3}\end{array}$ \\
\hline
\end{tabular}

\section{Introduction}

The existing method of power performance testing according to IEC $61400-12^{-1}{ }^{1)}$ is costly and time consuming because met-mast should be located at a distance of between $2 \sim 4$ rotor diameter from a wind turbine under test. It is not possible to obtain a reliable power curve of a wind turbine located at a distance of more than 4 rotor diameter from met-mast since the correlation between wind speed and electric power output will be low. For that reason, many studies on power performance verification by nacelle wind speed have been carried out.

Albers et $\mathrm{al}^{2}{ }^{2)}$ reported that wind power performance verification using nacelle wind speed will reduce the cost to a third of that using met-mast wind speed. The study on relationship between wind speed derived from the measured electric power and wind speed measured from nacelle anemometer to verify wind direction under wake was conducted by Albers et al. ${ }^{3)}$ Smith et al. ${ }^{4}$ found that there was specific correlation between nacelle and met-mast wind speed through various experiments.

IEC $61400-12-2^{5)}$ was published recently to provide a methodology to obtain power curves of wind turbines without met-mast based on nacelle wind speed. The purpose of this study is to carry out power performance testing of a wind turbine which is more than 4 rotor diameter away from a met-mast in accordance with the procedure regulated by IEC $61400-12-2$. The uncertainty was not evaluated in this study, and that is our next research subject.

\section{Test setup}

The test site, test conditions, specification of wind turbine generator, WTG, and measurement equipment are shown in Fig. 1, Table 1, Table 2, and Table 3. The studies by Kim et al. ${ }^{6)}$ and Her et al. ${ }^{7)}$ on power performance testing in compliance with IEC 61400-12-1 were conducted in this test site.

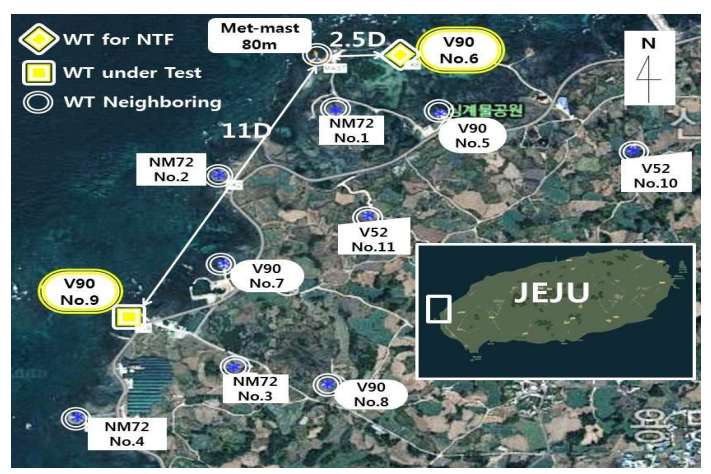

Fig. 1 Test site 
Table 1 Test conditions

\begin{tabular}{c|c}
\hline Item & Description \\
\hline Measurement period & 2009.09.17. 2010.02.17. \\
\hline Measurement location & $\begin{array}{c}\text { HanKyung Wind Farm, } \\
\text { Jeju city, Rep. of Korea }\end{array}$ \\
\hline WTG for NTF & V90 No.6, 2.5D from met-mast \\
\hline WTG under test & V90 No.9, 11D from met-mast \\
\hline
\end{tabular}

Table 2 Specification of WTG under test

\begin{tabular}{c|c}
\hline Item & Description \\
\hline WTG model & Vestas 90 3MW \\
\hline Diameter / Hub height & $90 \mathrm{~m} / 80 \mathrm{~m}$ \\
\hline $\begin{array}{c}\text { Cut-in / Rated /Cut-out } \\
\text { Wind speed [m/s] }\end{array}$ & $3.5 / 15 / 25$ \\
\hline Control / RPM(rated) & Active pitch / 16.1rpm \\
\hline
\end{tabular}

Table 3 Measurement equipment

\begin{tabular}{c|c|c}
\hline Parameter & Sensor type & Height AGL \\
\hline Mast WS & Cup anemometer & $80 \mathrm{~m}$ \\
\hline Mast WD & Potentiometer & $80 \mathrm{~m}$ \\
\hline Pressure & Vaisala PTB100A & $1 \mathrm{~m}$ \\
\hline Temperature & Thies 2.1280.00.141 & $77 \mathrm{~m}$ \\
\hline Nacelle WS & FT ultrasonic & $80 \mathrm{~m}$ \\
\hline Nacelle WD & $\begin{array}{c}\text { FT ultrasonic, } \\
\text { Revised by the } \\
\text { specific offset }\end{array}$ & $80 \mathrm{~m}$ \\
\hline Electric power & $\begin{array}{c}\text { Vestas SCADA, Verified by } \\
\text { comparing transducer end signals }\end{array}$ \\
\hline D Data acquisition sampling rate : 1Hz \\
Data set store period : 10 minute
\end{tabular}

\section{Nacelle transfer function}

The nacelle wind speed data is not suitable for power performance testing because nacelle wind flow is disturbed due to rotation of the wind turbine rotor. For that reason a NTF assesses the effect of the wind turbine rotor on nacelle wind speed and predicts what free wind speed would be at the upwind.

For NTF derivation, the hub-height free wind speed measured by anemometer on the met-mast and the nacelle wind speed of No.6 WTG that is located at 2.5 rotor diameter from met-mast were used in this investigation.

\subsection{Measurement sector for NTF}

From both of the met-mast and the No.6 WTG, the directions having significant obstacles and neighboring WTGs were excluded from NTF measurement sector according to IEC 61400-12-1. As a result, for No.6 WTG the wind speed data coming from directions from $252^{\circ}$ to $46^{\circ}$ were available for NTF establishment.

\subsection{Terrain evaluation}

The test site should be assessed to check the effect of wind flow distortion due to topographical variation. One should identify whether the site is complex and power output of WTG is available without a site calibration for accurate power performance testing.

Fig. 2 shows circular area for terrain evaluation, where $\mathrm{L}$ is a distance from WTG to met-mast. The circle was divided into the measurement sector and the excluded sector for measurement.

The terrain evaluation was carried out in compliance with the regulations of IEC 61400-12-1. The result is shown in Table 4. Evaluated maximum slopes and maximum 
terrain variations were lower than the criteria. Accordingly, no site calibration was needed.

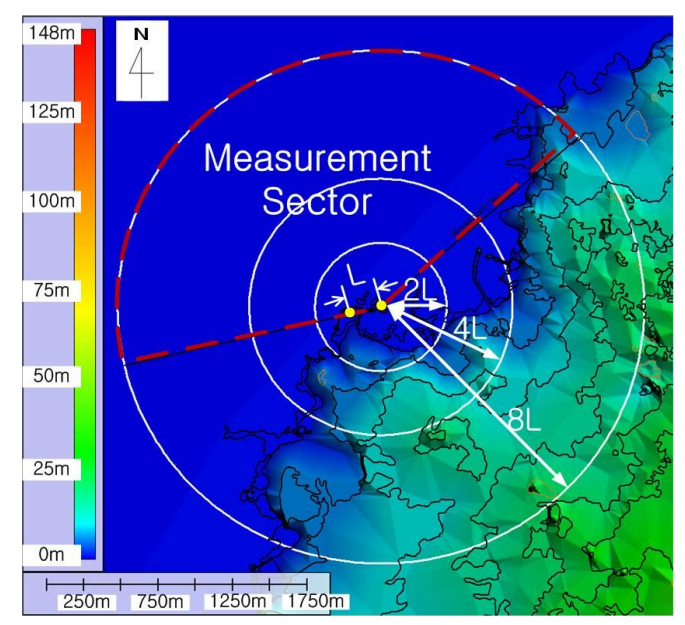

Fig. 2 Area for terrain evaluation

Table 4 Terrain evaluation

\begin{tabular}{c|c|c|c}
\hline Distance & Sector & $\begin{array}{c}\text { Maximum } \\
\text { slope[\%] }\end{array}$ & $\begin{array}{c}\text { Max. terrain } \\
\text { variation[m] }\end{array}$ \\
\hline$<2 \mathrm{~L}$ & $360^{\circ}$ & $0.63<3 *$ & $\begin{array}{c}4.40 \\
<0.04(\mathrm{H}+\mathrm{D}) *\end{array}$ \\
\hline$\geq 2 \mathrm{~L} \&<4 \mathrm{~L}$ & $\begin{array}{c}\text { Measurement } \\
\text { sector }\end{array}$ & $0.00<5 *$ & $\begin{array}{c}0 \\
<0.08(\mathrm{H}+\mathrm{D}) *\end{array}$ \\
\hline $2 \mathrm{~L} \&<4 \mathrm{~L}$ & $\begin{array}{c}\text { Outside } \\
\text { Measurement } \\
\text { sector }\end{array}$ & $1.74<10 *$ & $\begin{array}{c}\mathrm{Not} \\
\text { application }\end{array}$ \\
\hline$\geq 4 \mathrm{~L} \&<8 \mathrm{~L}$ & $\begin{array}{c}\text { Measurement } \\
\text { sector }\end{array}$ & $0.46<10 *$ & $\begin{array}{c}7.39 \\
<0.13(\mathrm{H}+\mathrm{D}) *\end{array}$ \\
\hline
\end{tabular}

* Criteria in accordance with IEC 61400-12-1 $\mathrm{H}$ : Hub height $=80 \mathrm{~m}, \mathrm{D}$ : Rotor diameter $=90 \mathrm{~m}$

\subsection{Correlation of nacelle and met-mast wind speed}

Simultaneously measured wind speed data from the met-mast and the nacelle of No.6 WTG were plotted in Fig. 3. The met-mast wind speed data were binned against the nacelle wind speed data according to the method of bins with $0.5 \mathrm{~m} / \mathrm{s}$ interval.
Then each linear interpolation between bins was made using the following formula :

$$
\begin{aligned}
V_{\text {free }}= & \left(V_{\text {free }, i+1}-V_{\text {free }, i}\right) /\left(V_{\text {nacelle }, i+1}-V_{\text {nacelle }, i}\right) \\
& \times\left(V_{\text {nacelle }}-V_{\text {nacelle }, i}\right)+V_{\text {free }, i}
\end{aligned}
$$

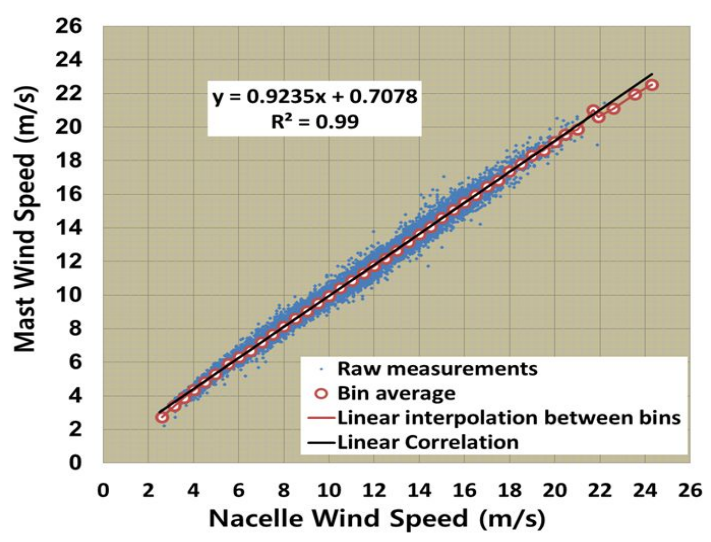

Fig. 3 Correlation of met-mast and nacelle wind speed

The fitted linear correlation, as shown in Fig. 3, can be used for free wind speed estimation. Energy research Center of the Netherlands, ECN, conducted the study on wind farm efficiency using the method of fitted linear correlation. ${ }^{8)}$ In this study, to obtain a more accurate result, all of nacelle wind speed data were corrected by each linear equation between neighboring bins derived by NTF for obtaining free wind speed.

\subsection{Verification of NTF}

The met-mast wind speed and nacelle wind speed corrected by NTF should be compared as form of binned power curve as well as AEP to verify NTF. The power curve derived from nacelle wind speed corrected by NTF is named as Nacelle Power Curve, NPC. 
According to IEC 61400-12-2, the maximum difference in power per bin should be less than $1 \%$ of bin's power or $0.5 \%$ of rated power. Table 5 shows the power differences of bins. All the differences were less than the criterion of $15 \mathrm{~kW}$, which is $0.5 \%$ of the rated power.

The AEPs were calculated using power curves with Rayleigh distribution supposing availability of $100 \%$. The maximum difference in AEP should be less than $1 \%$ for annual average wind speed $4 \mathrm{~m} / \mathrm{s}$ to $11 \mathrm{~m} / \mathrm{s}$ at hub height. Table 6 shows the AEP differences. The differences in AEPs were less than the criteria.

Accordingly, the NTF was verified by Tables 5 and 6. Thus the NTF is applicable to other nacelle wind data to estimate free wind speed.

Table 5 Power differences of bins

\begin{tabular}{c|c|c|c|c}
\hline $\begin{array}{c}\text { Bin } \\
\text { no. }\end{array}$ & $\begin{array}{c}\text { No.6 WTG } \\
\text { mast WS } \\
{[\mathrm{kW}]}\end{array}$ & $\begin{array}{c}\text { No.6 WTG } \\
\text { nacelle WS } \\
{[\mathrm{kW}]}\end{array}$ & $\begin{array}{c}\text { Difference } \\
{[\mathrm{kW}]}\end{array}$ & $\begin{array}{c}\text { Criterion } \\
{[\mathrm{kW}]}\end{array}$ \\
\hline 8 & 58 & 58 & 0 & 15 \\
\hline 9 & 108 & 112 & 4 & 15 \\
\hline 10 & 171 & 175 & 4 & 15 \\
\hline 11 & 251 & 254 & 4 & 15 \\
\hline 12 & 363 & 359 & 4 & 15 \\
\hline 13 & 454 & 452 & 2 & 15 \\
\hline 14 & 566 & 560 & 4 & 15 \\
\hline 15 & 692 & 688 & 4 & 15 \\
\hline 16 & 821 & 814 & 7 & 15 \\
\hline 17 & 1011 & 996 & 15 & 15 \\
\hline 18 & 1235 & 1225 & 10 & 15 \\
\hline 19 & 1465 & 1459 & 6 & 15 \\
\hline 20 & 1697 & 1701 & 4 & 15 \\
\hline 21 & 1922 & 1929 & 8 & 15 \\
\hline 22 & 2141 & 2148 & 7 & 15 \\
\hline 23 & 2356 & 2362 & 6 & 15 \\
\hline 24 & 2551 & 2551 & 0 & 15 \\
\hline 25 & 2704 & 2713 & 9 & 15 \\
\hline 26 & 2819 & 2826 & 7 & 15 \\
\hline 27 & 2903 & 2905 & 2 & 15 \\
\hline 28 & 2944 & 2950 & 6 & 15 \\
\hline 29 & 2972 & 2977 & 5 & 15 \\
\hline 30 & 2986 & 2988 & 2 & 15 \\
\hline & & & & \\
\hline
\end{tabular}

Table 6 AEP differences

\begin{tabular}{c|c|c|c|c}
\hline $\begin{array}{c}\text { Annual } \\
\begin{array}{c}\text { avg. WS } \\
{[\mathrm{m} / \mathrm{s}]}\end{array}\end{array}$ & $\begin{array}{c}\text { AEP }_{-} \\
\text {Mast PC } \\
{[\mathrm{MWh}]}\end{array}$ & $\begin{array}{c}\text { AEP }_{-} \\
\text {[MW PC }\end{array}$ & $\begin{array}{c}\text { Difference } \\
{[\mathrm{MWh}]}\end{array}$ & $\begin{array}{c}\text { Criteria } \\
{[\mathrm{MWh}]}\end{array}$ \\
\hline 4 & 1572 & 1567 & 5 & 16 \\
\hline 5 & 3187 & 3179 & 8 & 32 \\
\hline 6 & 5225 & 5215 & 10 & 52 \\
\hline 7 & 7402 & 7394 & 8 & 74 \\
\hline 8 & 9440 & 9435 & 5 & 94 \\
\hline 9 & 11130 & 11127 & 3 & 111 \\
\hline 10 & 12371 & 12370 & 1 & 124 \\
\hline 11 & 13156 & 13158 & 2 & 132 \\
\hline
\end{tabular}

\section{Nacelle power curve}

The NTF was applied to the nacelle wind data of No.9 WTG under test. It is located at 11 times the rotor diameter from the met-mast.

\subsection{Measurement sector for NPC}

The disturbed wind direction sector from No.9 WTG was excluded according to the IEC 61400-12-1. Fig. 4 shows the measurement sector and excluded sector for power performance testing of No.9 WTG.

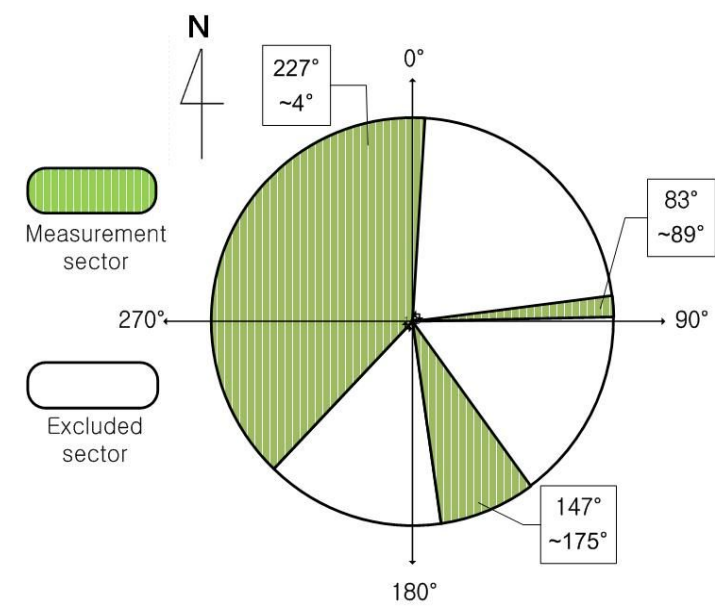

Fig. 4 Measurement sector for No.9 WTG 
There should be no wind distortion in the measurement sector. Even in the excluded sector, a NTF can be valid, or in measurement sector, a NTF cannot be valid. Thus, it is necessary to check if there is wind distortion in the measurement sector through self-consistency check.

Fig. 5 shows self-consistency check of No.9 WTG. The rectangular parts are excluded sectors. $V_{p}$ is wind speed derived from power output in combination with NPC. $V_{\text {free }}$ is wind speed calculated by nacelle wind speed in combination with NTF. Ideally, $V_{p}$ should be identical to $V_{\text {free, }}$ if there is no wind distortion.

Within the excluded sector, there were high ratios of $V_{p}$ to $V_{\text {free }}$ at directions having the neighboring wind turbines. In the measurement sector, the ratios were within allowable limit, which is between 0.97 and 1.03. Accordingly, it was verified that the wind data in the measurement sector was available for NPC of No.9 WTG.

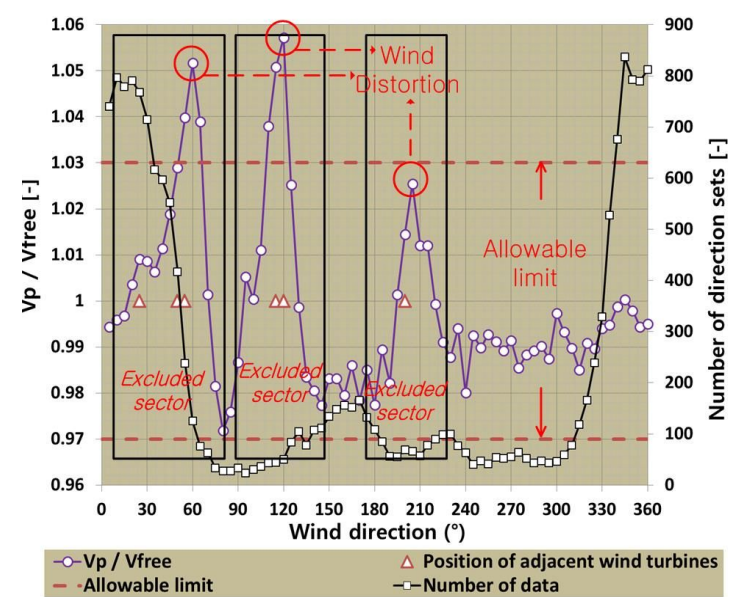

Fig. 5 Self-consistency check for No.9 WTG

\subsection{Terrain classification for NTF}

To apply the NTF, the terrain on which NTF was established should be similar to the terrain where the NTF would be applied. According to IEC 61400-12-2, assessment of ruggedness index, RIX, and terrain slope for the two local terrains should be made, and the difference between the two final terrain classes should be \pm 1 for application of the NTF.

Since No.6 WTG and No.9 WTG are situated on the coast close to the sea, the two local terrains are very flat. The terrain classification led that the two local final terrain classes were 1 . Thus, local terrains do not influence the NTF and the NPC so that the NTF can apply to the wind speed data from the nacelle of the No.9 WTG under test.

\subsection{Power performance database}

In order to represent the power curves more accurately, the wind speed data was normalized to reference air density at sea level according to the following formula :

$$
V_{n}=V_{\text {free }} \times\left(\frac{\rho_{10 \mathrm{~min}}}{\rho_{0}}\right)^{1 / 3}
$$

Fig. 6 shows scatter plots of the average, the maximum, the minimum, and the standard deviation of measured power outputs of No.9 WTG. The wind speed ranges from $4 \mathrm{~m} / \mathrm{s}$ to $21.5 \mathrm{~m} / \mathrm{s}$. Each bin with $0.5 \mathrm{~m} / \mathrm{s}$ interval has more than three data, which is minimum requirements for 
reliable power curve according to IEC $61400-12-1$. There are no significant signal noise or data influenced by mounting structure.

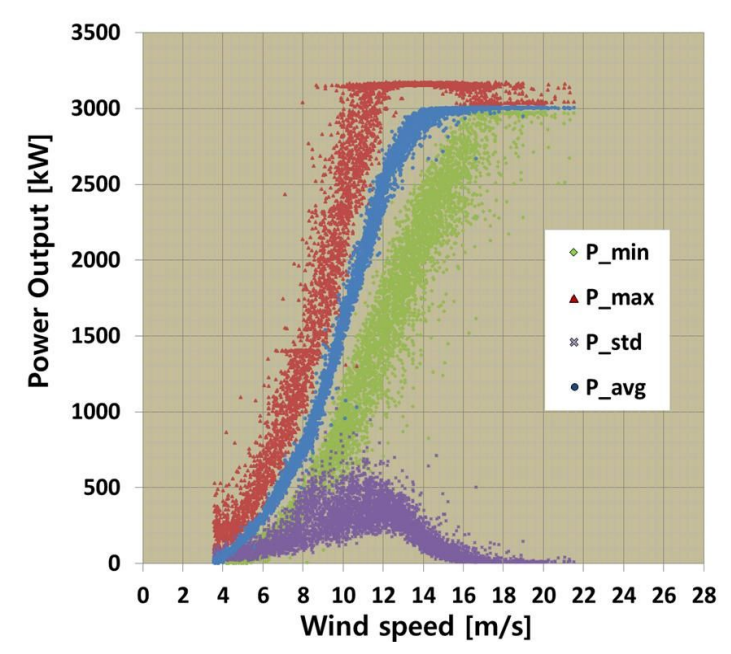

Fig. 6 Power performance scatter plots of No.9 WTG

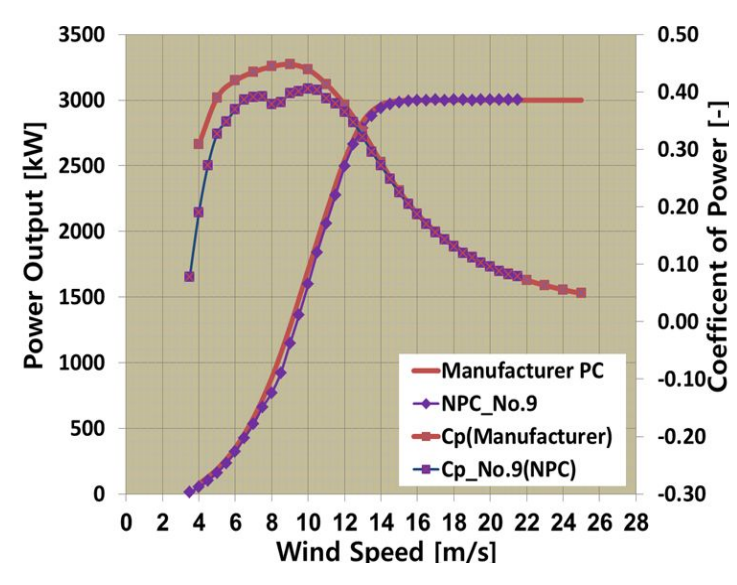

Fig. 7 NPC of No.9 WTG and power curve of the manufacturer

\subsection{NPC of WTG under test}

Fig. 7 shows the NPC and the power coefficient, $\mathrm{C}_{\mathrm{p}}$, of No.9 WTG, compared to the manufacturer's. Overall power outputs of bins were well matched with those offered by the manufacturer. The power outputs and $\mathrm{C}_{\mathrm{p}}$ at wind speed lower than rated wind speed of $15 \mathrm{~m} / \mathrm{s}$ were slightly lower than those of the manufacturer's. At wind speed higher than the rated wind speed, the power output and $\mathrm{C}_{\mathrm{p}}$ of both No.9 WTG and manufacturer's are almost the same.

\section{Conclusions}

(1) The power performance testing was successfully conducted using the NTF in compliance with the procedure provided by IEC $61400-12-2$.

(2) The reasonable NTF was derived from the nacelle and the met-mast wind speed. It was verified by analysing the differences of the power of bins and the AEP.

(3) Overall the NPC of wind turbine under test was matched well with the power curve provided by the manufacturer.

\section{ACKNOWLEDGEMENTS}

This work was supported by the Human Resources Development of the Korea Insitute of Energy Technology Evaluation and Planning(KETEP) grant funded by the Korea government Ministry of Knowledge Economy.(NO.200940202000200)

\section{REFERENCES}

1. International Electrotechnical Commission (IEC), Wind Turbines - Part 12-1 : Power 
Performance Measurements of Electricity Producing Wind Turbines, 1st ed, 2005.

2. Albers, A., Gerhard, G., Wind Farm Performance Verification, DEWI Magazin Nr.14, pp.7 8, 1999.

3. Albers, A., Klug, H., Power Performance Verification, EWEC Conference, 1999.

4. Smith, B., Link, H., Applicability of Nacelle Anemometer Measurements for Use in Turbine Power Performance Tests, AWEA's Wind Power Conference, 2002.

5. International Electrotechnical Commission (IEC), Wind Turbines - Part 12-2 : Power Performance of Electricity Producing Wind Turbines based on Nacelle Anemometry, 1st ed, 2013.

6. Kim, K.H., Hyun, S.G., Power Performance Testing and Uncertainty Anlaysis for a 3MW Wind Turbine, J.Korean Solar Energy Society, Vol.30 No.6, 2010.

7. Her, S.Y., Kim, K.B., Huh, J.C., Analysis of Power Performance and Uncertainty for a 3.0MW Wind Turbine, Conference of J. Korea Society for Computational Fluids Engineering, 2010.

8. Curvers, A., Van der Werff, P.A., OWEZ WIND FARM EFFICIENCY, ECN-E-08-092, P11 13, 2009. 